\title{
Letras de Câmbio das Sociedades de Crédito e Financiamento*.
}

\author{
Félix Ruiz Alonso
}

\section{Introdução.}

As Letras de Câmbio das Companhias de Crédito e Financiamento, que são Letras de Câmbio com uma função proeminente, têm sido o grande instrumento do Mercado de Capitais do Brasil. Continuam sendo os títulos mais procurados no mercado.

Parece-nos que, neste momento, êsses títulos de crédito merecem uma consideração tôda especial, precisamente pela significação transcendental que têm para a nossa economia em desenvolvimento, dado o volume crescente que atingem.

Graças às Letras de Câmbio das Companhias Financiadoras, os recursos que se situavam, no passado recente, em áreas especulativas ou improdutivas (poupança em moedas estrangeiras; aplicações no mercado "pararelo", etc.) entraram no mercado de capitais e se aplicam agora no comércio e na indústria. Simultâneamente, a nossa população, que sempre se caracterizou por hábitos contrários à poupança, apreendeu a poupar. Hoje não só as grandes economias, mas precìpuamente a pequena e média poupança, são orientadas ao mercado de "Letras de Câmbio".

*. Trabalho apresentado, no segundo ano do Curso de Especialização da Faculdade de Direito da U.S.P. em 1967. 
Êste estudo, cujo objeto é precisamente êsse título de crédito, o estudará sob vários aspectos: as peculiaridades da "Letra de Câmbio" das Financiadoras; a institucionalização dêsses títulos na nossa economia, a função das Financeiras e comercialização do aceite. No final acrescentamos alguns aspectos de política fiscal.

Propositadamente não se chega a conclusões radicais, embora se suscitem, neste trabalho, várias questões principalmente à volta do "crédito de aceitação", numa tentativa de diferenciá-lo do "crédito comum", para salientar as "Letras de Câmbio".

Antes de finalizar esta breve introdução quero agradecer a colaboração do Dr. Filomeno Joaquim da Costa, sob cuja orientação realizei êste trabalho.

SUMÁRIo: I - "A Letra de Câmỉio: Generalidades". 1. Noção de Letra de Câmbio. 2. As partes da Cambial: Sacador, Sacado e Tomado. 3. O Direito Cartular. II - "As partes da Letra de Câmbio das Financiadoras". 4. O Sacador: o creditado. 5. O Sacado: o financiador. 6. O Tomador: o portador. III - "Crédito das Financiadoras". 7. As operações das Financiadoras. 8. Operações Não-Bancárias. 9. O Crédito Bancário e o das Financiadoras. IV - "Crédito de Aceitação" 10. O Crédito de aceitação. 11. Modalidades mais usuais do crédito de aceitação. 12. A Institucionalização do aceite. $\mathrm{V}-$ "A Negociação das "Letras de Câmbio". 13. A Venda das "Cambiais". 14. O Desconto das "Cambiais" 15. Os Particulares Emprestantes.

1. Embora êste trabalho cuide especìficamente das Letras de Câmbio das Companhias de Crédito e Financiamento, difìcilmente poder-se-ia tratar delas, sem se tratar prèviamente da Letra de Câmbio, em geral. Todavia não será necessário analisar aqui a cambial duma forma exaustiva, sendo suficiente relembrar os seus aspectos essenciais a fim de, em seguida, compreender-se melhor as peculiari- 
dades e características da cambial própria das Financiadoras. A Letra de Câmbio é definida no nosso direito comercial $^{1}$ como uma ordem de pagamento, a qual deve conter, por extenso, os seguintes requisitos no contexto:

$$
\begin{aligned}
& \text { I - A denominação "Letra de Câmbio"2. } \\
& \text { II - A soma de dinheiro a pagar. } \\
& \text { III - A assinatura da pessoa que ordena pagá-la; } \\
& \text { chamada comumente: sacador. } \\
& \text { IV - } 0 \text { nome da pessoa que deve pagá-la; chama- } \\
& \text { da comumente: sacado. } \\
& \text { V - O nome da pessoa a quem deve ser paga ou } \\
& \text { tomador. A letra pode ser ao portador. }
\end{aligned}
$$

Além dêsses há outros requisitos, porém não necessários, como são a data e o lugar de emissão, data de vencimento e lugar de pagamento.

Se pretendêssemos dar uma noção mais sintética, poderiamos dizer que a Letra de Câmbio é um título de crédito pelo qual uma pessoa, o sacador (ordinàriamente, credor), ordena a outra, o sacado (ordinàriamente, devedor dela), que pague determinada importância a um terceiro, tomador (ou beneficiário da ordem).

Esta, a concepção histórica da letra, que pressupõe. como fàcilmente se depreende, uma relação obrigacional entre o sacador (credor) e o sacado (devedor). Por exemplo, se o médico Caio prestou serviços profissionais ao paciente Cícero, poderá sacar uma letra de câmbio contra o paciente devedor, pelo valor da consulta, a fim de reaver-lhe a importância. O sacado (Cícero) poderá ainda aceitar a Letra, o que é praxe fazer, no mesmo

1. Título I da Lei $n .^{\circ} 2044$ de 31.12.1908.

2. Diz ainda o artigo $10^{\circ}$ da lei 2044 , em referência, que poderá levar a expressão equivalente da língua em que fôr emitida "lettre de change"; "lettera di cambio"; "gezogener Wechsel" etc.. O que abre tôda uma série de possibilidades a êste título, no campo internacional, comercial e financeiro. 
título, transversalmente. Naturalmente o aceite confirmará a validade do saque.

2. A Letra de Câmbio emite-se, em princípio, em benefício do próprio sacador, mas êste, pelas razões que forem, poderá indicar um terceiro como beneficiário do saque.

Ponhamos por caso que o médico, Caio, de nosso exemplo, tenha recebido o valor da consulta de um amigo: de Clemente. Neste caso poderá indicar na carta formal dirigida ao paciente Cícero, que pague a Clemente.

Ainda a nossa lei, permite que o beneficiário não seja designado, mas fique no anonimato. É o caso da chamada "Letra de Câmbio ao Portador".

Em conclusão, temos três sujeitos beneficiários possíveis, na nossa cambial: $1 .^{\circ}$ o próprio sacador, $2 .^{\circ}$ um terceiro designado e $3 .^{\circ}$ um anônimo ou portador. Ainda caberia, se se desejasse, um quarto caso: em que o portador fôsse o mesmo sacador.

Dentre os beneficiários interessa salientar o fato de ter admitido a nossa lei a Letra ao Portador, contràriamente ao que a legislação uniforme de Genebra concluíu e recomendou aos países participantes, entre os quais o Brasil se incluía ${ }^{3}$. Evidentemente o legislador pátrio em 1908 levou em consideração as inumeráveis vantagens que se depreendiam dos títulos ao portador, máxime num país em formação, onde o rigorismo excessivo prejudicaria.

As Letras podendo ser ao portador, posteriormente, permitiriam o lançamento do título objeto de nosso estudo, que é ao portador, e conseguiu-se assim a captação de um volume amplíssimo de recursos, graças ao anonimato dos tomadores.

3. A Lei Uniforme relativa às Letras de Câmbio e Notas Promissórias foi assinada pelo Brasil, representado por Deodécio de Campos, em Genebra, aos 7.6.30. Embora difìcilmente se possa contestar a vigência "de iure" da lei Uniforme, todavia é ponto pacífico que de fato não rege os nossos usos cambiários. A Letra de Câmbio ac portador, concretamente, é uma realidade inconteste, no Brasil. 
3. Pondo de parte outras considerações gerais sôbre a Letra de Câmbio, interessa aqui destacar algumas de suas características singulares, por estarem enquadradas entre os títulos de crédito, no chamado direito literal ou cartular. (da voz italiana "cartolare").

As características dos títulos são:

1) A Letra de Câmbio tem, por si só, valor constitutivo. Isto significa que não interessa a relação originária, básica ou fundamental de que se origina. Pouco importa se o médico do nosso exemplo desempenhou bem os seus cuidados profissionais ou se Cícero teve uma recaída posterior pela qual se recuse a pagar a consulta. O fato que não admite discussão é o saque explicitado por extenso de Caio contra Cícero.

A relação cambiária, com base no direito cartular, é independente da relação básica, subjacente ou fundamental que exista entre as partes da Letra; é constitutiva "per se". Cícero deverá pagar, sem mais discussão ao médico Caio. Só depois, se o quiser, poderá ir contra êle, com base na relação originária.

2) A Letra de Câmbio não guarda relação com a sua causa. "Inclusive pode ocorrer que não exista nenhuma relação subjacente. Mas exista ou não exista, o título cambiário nada tem com a relação jurídica que subjaz ou sôbrejaz. Por isso mesmo que êle não tem causa, que é ôco de causa, é que se presta a encobrir ou cobrir a causa de alguma relação jurídica estranha. Encobrir ou cobrir, porém não fazê-la sua"4.

Esta doutrina jurídica faz da cambial um título extraordinàriamente indicado para a concepção $e$

4. Pontes DE MIRANDa: Tratado de Direito Cambiário, Vol. I, "Letras de Câmbio", São Paulo, 1954, p. 20. 
configuração das mais variadas operações. Pode-se emitir a cambial sem relação obrigacional pré-existente, pode-se chegar ao extremo de sacar Letras contra pessoas que nada devem ao sacador, são as chamadas Letras de favor, ou então emití-las contra pessoas que, embora na data da emissão não são devedoras, se-lo-ão na data do vencimento da Letra. Este é o caso das "cambiais" emitidas contra a Financiadora, que nada deve ao sacador, para que as aceite. Mas sôbre esta particularidade voltaremos logo.

3) Ainda se fala de outras propriedades, tais como de um "direito autônomo"5 que desvincularia o título de sua origem e estados anteriores; de um "direito abstrato"" que justifica a relação cambiária e tôda a livre movimentação do título, etc. Mas parece-nos que tudo isto se inclui atualmente no já elaborado direito cartular ${ }^{7}$.

4. Dissemos, falando da relação obrigacional subjacente à Letra de Câmbio, que normalmente o sacador é o credor da obrigação. No exemplo que púnhamos, o sacador é o médico, Caio, a quem o sacado, Cícero, deve certa importância.

Seria absurdo que o sacador fôsse Cícero, contra o credor Caio. Mas esta inversão, à primeira vista incom preensivel, é a que aparece nas cambiais das financiadoras. A pessoa física ou juridica que demanda o crédito $\dot{e}$

5. Ascareill, Tulio - Teoria Geral dos Títulos de Crédito, Saraiva \& Cia. Editores, São Paulo, 1943, p. 78.

6. Cfr. Ferreira, Waldemar, op. cit., p. 46-47, Pontes de MrRANDA, op. cit., p. 20-21, Ascarelli, Tulio, op. cit.

7. AsCarelli, Tulio: “... A tendência dêstes estudos em procurar princípios básicos fundamentais, mesmo quanto à natureza co direito cartular, comuns a todos os títulos de crédito" Teoria Geral dos Títulos de Crédito, trad. Nicolau Nazo, Saraiva, São Paulo, 1943. p. 364 . 
quem saca as Letras de Câmbio - e precisamente as saca contra a mesma Companhia credora, que lhe proporcionará os recursos.

Ponhamos como exemplo o caso de uma conhecida cadeia de lojas de geladeiras que solicitasse crédito e o obtivesse. Se a forma usada para a sua concessão fôsse o chamado "contrato de abertura de crédito", com Letras de Câmbio, então as lojas seriam as sacadoras das cambiais e a Companhia Financiadora seria o sacado.

Esta situação, que parece anômala, se justifica com base em dois aspectos peculiares destas operações, a saber: a) provisão e b) o crédito de aceitação:

a) a provisão consiste numa série de garantias, as mais variadas, que possibilitarão ao financiador ter os fundos correspondentes do sacador, na altura aproximada do vencimento.

A provisão ordinàriamente é feita mediante títulos duplicatas, que se entregam em caução, e que vencendo antes do prazo do vencimento das Letras, asseguram ao financiador a cobertura da importância devida ${ }^{8}$. Chegado o vencimento das Letras, graças à provisão de fundos, normaliza-se a situação das partes, sacador e sacado, como credor e devedor respectivamente conforme aparecem na cambial: o sacador terá provido os recursos à Companhia sacada, e esta será realmente devedora da importância a pagar no vencimento.

Continuando com nosso exemplo, a Companhia de Crédito e Financiamento terá em seu poder, na data do vencimento, fundos das lojas de geladeiras

8. Quando o financiador não cauciona duplicatas, emitidas pelo creditado, costuma exigir dêle em garantia, segundo permite a atual regulamentação dêstes financiamentos, quer bens alienados fiduciàriamente, quer bens em penhor. Além disso, existem sempre notas promissórias emitidas pelo financiado a favor da Financiadora, e com avais suficientes, que garantem a provisão dos fundos necessários antes do vencimento das Letras de Câmbio. 
e portanto estas serão credoras daquela. O saque, portanto, que foi feito, estará regularizado no vencimento.

b) o crédito de aceitação fundamenta-se no contrato de provisão a que acima nos referimos. Evidentemente, dada a abstração das cambiais a respeito de sua origem ou fundamento, o banqueiro ou qualquer outra pessoa poderia aceitar cambiais sacadas contra ela por puro favor e sem mais exigências - mas é desnecessário lembrar aqui que banqueiro nenhum, dada a prudência e segurança que os caracteriza, aceitaria letras sem ter a certeza da necessária provisão.

$O$ crédito de aceitação é o crédito que se obtém porque um banqueiro ("banker's acceptance") ou uma sociedade solvente se presta a pôr a sua assinatura, aceitando o saque contrário de outrém. Quer dizer, em primeiro lugar se obtém o aceite e em seguida, graças a isso, se obterá também o dinheiro.

"Mediante o uso dêste procedimento original de financiamento, o banqueiro aceitante tem a possibilidade de estender o crédito de que êle goza e de beneficiar com êle o seu cliente comercial, sem desembolsar importância alguma e sem imobilizar quaisquer fundos"9.

$O$ crédito de aceitação não é novidade nos usos bancários. Desde longa data os banqueiros, aproveitando a agilidade cambial, outorgam o seu aceite a clientes a fim de efetuarem os seus negócios. Por outro lado, tomam as garantias suficientes a fim de possuirem, no vencimento da cambial, a cobertura de que precisarão.

9. CORCelle, Carios, Créditos por aceptación en los Bancos, em "Industrias y Finanzas", a. XV, n. ${ }^{\circ}$ 171, Buenos Aires, Março, 1936, p. 4.308 . 
No nosso país, por exemplo, por ocasião da exportação do café, os comissários aceitavam Letras sacadas pelos agricultores e, a seguir, as descontavam nos Bancos. No vencimento, os comissários-exportadores pagavam as cambiais com o produto da exportação da própria safra.

A aceitação, portanto, para se conseguir ou reforçar o crédito de outrém, não é novidade. A novidade está no aparecimento de banqueiros especializados no aceite, e ainda no seu entrosamento com uma determinada forma de financiamento. As Companhias de Crédito e Financiamento são Companhias que se constituem precipuamente para prestarem o seu aceite; e usá-lo como alavanca para obterem assim os recursos de que precisa a clientela a ser financiada.

5. À primeira vista, parece um contra-senso que o sacador seja o devedor e o sacado (seja) precisamente a financiadora, que proporciona os recursos.

Êste contrasenso aparente se justifica em função do crédito de aceitação. Em realidade a financiadora não é nem devedora originàriamente nem empresta dinheiro embora exista justa causa para sacar contra ela.

Estas noções, ao longo dêste trabalho, ir-se-ão esclarecendo até se tornarem patentes. Contudo, a provisão de fundos faz que a financiadora, na ocasião do vencimento, seja realmente devedora, segundo consta formalmente na Jetra.

De outro lado, o fato de que a financiadora não empreste pròpriamente numerário e que, por conseguinte, não se possa considerar por isso credora, se depreende da própria atividade dela, simples intermediária entre os aplicadores - que são os verdadeiros mutuantes - e os financiados. 
6. Título ao portador é o escrito que consigna a obrigação de pagar a quem quer que se apresente com êle ${ }^{10}$.

"O simples possuidor legitíma-se como titular do direito, e quem, no caso concreto, possuir o título, será por isso mesmo considerado titular"11. Os títulos de crédito ainda podem ser nominais e à ordem. Nestes casos, o tomador do título é expressamente mencionado, pelo seu nome, no título.

No caso das letras de cẩmbio, o legislador julgou conveniente concebê-los como títulos ao portador ${ }^{12}$. A razão que o conduziu a isso foi a consideração da função concreta que as cambiais teriam de desempenhar: seriam adquiridas pelos cidadãos de um país, note-se bem, com uma economia em estado inflacionário, com uma administração fiscal deficiente e com um importantíssimo mercado paralelo de capitais.

Se a circulação dêsses títulos, desde o início, fôsse controlada - como seria no caso em que os cidadãos compradores tivessem de fazer constar os seus nomes - o resultado a esperar seria pequeno. Era evidente a conveniência de que êsses títulos fôssem ao portador, a fim de se concentrar no mercado legal de capitais o volume gigantesco de recursos que se movimentavam marginalmente - como é do conhecimento geral. Realmente, o resultado atingido foi surpreendente excedeu amplamente quaisquer previsões: o total de cambiais em poder do grande público, no fim de 1967, alcançava a cifra dos

10! Cfr. Clóvis Bevilaqua, Código Civil Comentodo, vol. V, 1926, p. 276 .

11. Ascareldi, Tullio, Teoria Geral dos Títulos de Crédito, São Paulo, 1943, p. 225.

12. Ingles DE SouzA, H. Falando acêrca dos títulos ao portador, no Brasil, diz "Nêste assunto não se tem procurado seguir o regime dos países de que andamos sempre imitando alguma coisa". "Títulos ao portador no Direito Brasileiro", Rio de Janeiro, Livraria Francisco Alves, 1898, p. 78 . 
NCr\$ 1.800.000.000,00 (um bilhão e oitocentos milhões de cruzeiros novos) ${ }^{13}$. As cifras alcançadas são ainda irrisórias, já que os valores em questão recém nasceram.

A não identificação dos tomadores, para acabar, é não só o mais conveniente, no plano real, como se tem demonstrado, mas também essencial aos títulos ao portador. Pretender a identificação nos títulos ao portador seria um contrasenso ${ }^{14}$.

13. Almiro, Afronso: Letras de Câmbio: Excelente Papel, Conferência pronunciada no Conselho Téenico da "Confederação Nacional do Comércio", Rio de Janeiro, 28.9.1967. Nessa conferência, citou os seguintes dados:

Agôsto 1962 - 32 Companhias de Cambiais, NCr\$ 41.242.000, em LC.

Agôsto 1967 - 195 Companhias de Cambiais, NCr\$ 1.360.000.000, em L.C.

Por êstes dados se entrevê a importância dêste mercado e o seu rapidíssimo crescimento. Em agôsto de 67 , operavam exatamente 185 Companhias; sendo Bancos de Investimentos, de recente fundação, os 10 restantes estabelecimentos, devedores de $\mathrm{NCr} \$ 260.000 .000,00$ de aceitações.

Finalmente, no fim de dezembro de 67, eram 196 as Companhias e apresentavam exatamente um total de aceitações de NCr\$1.788.254.810,00 (um bilhão, setecentos e oitenta e oito milhões e duzentos e cincoenta e quatro mil e oitocentos e dez cruzeiros novos).

14. Referimo-nos à formalidade de ordem fiscal recente, que exige a identificação dos proprietários dos títulos, a fim de pagarem uma tributação menor sôbre a renda que auferirem. Poderão todavia permanecer no anonimato, pagando uma tributação maior. Embora mais gravosa para os portadores, a única fórmula cabível é a de não identificação. Manter a natureza das instituiçōes é principal e o fisco não pode cair em extremos, apoiado na autonomia das instituições fiscais. É extremamente perigoso desrespeitar os limites naturais das instituições.

Por outro lado, se a pretensão do legislador fiscal é conhecer os proprietários reais dos recursos investidos nas cambiais, não pode perder de vista que o possuidor do título no resgate pode não ser o seu real beneficiário. 0 tomador real do título poderia, no vencimento, entregá-lo fiduciàriamente a outra pessoa para que legitimamente $o$ 
7. Embora as Letras de Câmbio, pelo fato de "per se" constituirem direito, nada tenham a ver, no plano funcional, com a causa jurídica que lhes deu origem, não podemos esquecer que, na realidade, têm uma causa. No nosso caso, o contrato de abertura de crédito que as origina e suporta é a primeira peculiaridade a ter em conta. O crédito chamado de aceitação é um contrato de crédito especial, mas antes de nos adentrarmos nele, convém dar uma visão da atividade e operações das Financeiras.

A Portaria 309 de 1959, criando as Sociedades de Crédito e Financiamento, visa precisamente instaurar e regulamentar o crédito a médio e longo prazo - como é sabido.

$\mathrm{O}$ documento é amplo e o suficientemente flexível de maneira a permitir o desenvolvimento de uma atividade, então incipiente entre nós, sem tolhê-la ou cristalizá-la em moldes pré-fabricados. E'ssa atividade não deveria ser uma atividade bancária a mais. As novas instituições não poderão criar moeda escritural ou bancária. Poderão receber recursos de terceiros, a prazo médio e longo, mas de forma tal que os recursos já tenham uma aplicação. Não poderiam ficar depositados nas novas instituições, à livre disposição dos proprietários respectivos. A contacorrente movimentada por cheque não seria operação passiva destas Sociedades. Os recursos entram e saem integralmente.

"Os recursos de terceiros (diz a Portaria, em seu art. V) ... compreendem:

1) os destinados a operações pré-determinadas - hipótese em que não poderão ficar sem

cobrasse e, dêste fato, não se pode concluir que êsse fiduciário seja proprietário dos recursos aplicados. Se inquirido, pode ainda fazer saber, com pleno direito, que é um mero detentor fiduciário ou proprietário fiduciário do título e que não é o proprietário dos recursos. E confessando isso, ninguém poderá exigir-lhe outra coisa, por ser legítima essa posição, e perfeitamente cabível nos títulos ao portador, na forma de direito. 
aplicação, transcorrido(s) prazo(s) de quinze (15) dias;

2) o levantamento de recursos mediante quaisquer operações de crédito.

Ainda fala êsse artigo da constituição de fundos de participação como uma terceira forma de angariar recursos de terceiros. Mas o que importa salientar é a nova atividade, não bancária, exclusivamente intermediária, e também a liberdade que a Carta das Financiadoras deu para que os financiadores criassem as operações que melhor se adaptassem às novas características e condicões.

Sòmente no art. XXI, em que se fala expressamente das "operações" das Sociedades de Crédito e Financiamento, faz-se menção das Letras de Câmbio, por um lado, e da prestação do aceite, por outro ${ }^{15}$.

$\mathrm{Na}$ verdade o uso comercial e sucessiva regulamentação impuseram o "contrato de abertura de crédito" com "as Letras de Câmbio sacadas para o aceite da Sociedade" como operação típica das novas entidades mercantis.

Outras operações poderiam ter sido ou poderão ser utilizadas, mas, ao nosso estudo, interessa a operação que de fato se utiliza, e o título de crédito de que se serve.

A sucessão das coisas, para concluir, mostra que a Carta das Financiadoras não criou uma nova Letra de

15. "Observadas as demais disposições desta Portaria, poderão ser praticadas as seguintes operações:

Pelas sociedades de crédito e financiamento:

a) transações sob contratos de mútuo; financiamentos de compra ou venda, garantidos por qualquer dos meios admitidos na praxe bancária, exceto a caução de certificados de fundos instituídos pela própria sociedade, pelas sociedades congêneres ou pelas de investimentos; b) negociações de títulos de crédito, como duplicatas, notas promissórias, e letras de câmbio; c) participação em operações determinadas, de interêsse de outras emprêsas; d) financiamento da exportação ou importação de mercadorias; e) prestação de aceite ou aval em operações comerciais. 
Câmbio. Os Financiadores se servem da Letra de Câmbio comum, para atender ao crédito a prazo médio.

8. As Companhias de Crédito e Financiamento são instituições intermediárias em operações pré-determinadas. Isto quer dizer que os recursos que se captam de terceiros destinam-se a financiamentos já pré-estabelecidos. Mais concretamente, operação pré-determinada significa, sob o ponto de vista técnico-contábil, que ao exigível por responsabilidade cambial corresponde um lançamento igual ao realizável por operações cambiais. Os passos de uma operação desta classe de financiamento são os seguintes:

$10^{\circ}$ - A pessoa, física ou jurídica, que necessita do crédito, solicita-o à financiadora, sacando as Letras de Câmbio contra ela.

2. - A Financiadora, que tem um "know how" especializado $^{16}$, com base neste, aceita as letras e as desconta com particulares, ordinàriamente através de corretores, obtendo-se os recursos necessários após a venda das "Letras de Câmbio".

$3 .^{\circ}$ - Credita os referidos recursos, procedentes da colocação das Letras de Câmbio, na conta-corrente da pessoa financiada.

No contrato de crédito assinado entre o creditado e a Financiadora, faz-se especial menção dêste último fato: que só creditará o valor do crédito na medida em que se forem colocando as letras, sacadas pelo creditado, que a

16. Essse "know how" consiste em: $10^{\circ}$ Conhecimento aprofundado dos que solicitam o crédito, através de informações e cadastros; $\left.2 .{ }^{\circ}\right)$ Conhecimento dos sistemas ágeis e jurìdicamente seguros, para formalizar as operações; $3 .^{\circ}$ ) Clientela para colocação das "Letras de Câmbio"; $4 .^{\circ}$ ) Aparelhamento exigido para acompanhar até bom têrmo a operação; $5 .^{\circ}$ ) Diretorias e organizações que mereçam confiança, pelo seu nível ético e de compctência etc.. Por êstes requisitos se compreende a necessidade de sociedades formadas exclusivamente para reuní-los. São as Sociedades de Crédito e Financiamento. 
Financiadora se compromete a aceitar. Inclusive, entre os. documentos que acompanham o contrato, existe sempre uma carta, dirigida ao financiador, na qual o creditadosacador relaciona os saques e solicita os serviços do financiador para vender as Letras de Câmbio em questão. As importâncias procedentes da venda, à medida que se obtém, creditam-se na conta do financiado ${ }^{17}$.

9. O crédito concedido pelos banqueiros tradicionalmente é diferente. Não realizam os Bancos operações pré-determinadas. Por um lado, recebem os depósitos de terceiros e por outro lado, sem referência alguma aos credores, efetuam indeterminada e indiscriminadamente as suas operações ativas ${ }^{18}$. Para os credores só existe um devedor: o Banco. Ignoram a quem emprestou os depósitos. Isto permite aos estabelecimentos bancários, quando concedem crédito, colocarem imediatamente à disposição

17. No financiamento ao consumidor ou usuário final, que efetua uma compra à vista, naturalmente faz-se necessário pagar de imediato. Não entregando o preço, na hora, não se consumaria a compra-venda à vista. Nestes financiamentos especìficamente a Financeira vê-se na contingência de entregar a importância financiada antes de vender as correspondentes Letras de Câmbio.

Por conseguinte, nos financiamentos ao consumidor o desenrolar da operação se processa seguindo os passos inversos ao financiamento que poderíamos qualificar de típico. Primeiro se credita ao financiado e, em seguida, se vende a Letra para repôr a importância paga.

18. Essas operações ativas, os empréstimos, nascem precisamente da grande descoberta, verdadeiro fulcro da atividade bancária, que foi saber que mantendo um encaixe relativamente pequeno, dos depósitos, o restante poder-se-ia emprestar sem correr o menor risco.

De resto os empréstimos concedidos convertem-se em novos depósitos que ocasionam outros empréstimos. Esta a génese da chamada moeda escritural que vem a engrossar o meio circulante, somando-se ao papel moeda. No mundo moderno a moeda bancária rêm representando os 70 ou $75 \%$ aproximadamente do total dos meios de pagamento. Nos países desenvolvidos chega a ser inclusive mais de $75 \%$. Esta percentagem - como é sabido - está em função da percentagem de encaixe estabelecida pelo Banco Central em cada país. 
do financiado o valor do empréstimo. A fórmula usual é a de creditar-lhe na conta-corrente a importância acordada, da qual poderá dispor imediatamente.

O contrato de abertura de crédito que tradicionalmente se usava e estudava tinha como efeito imediato a concessão do crédito $^{19}$, já que o creditador efetuava o contrato sendo já possuidor dos recursos necessários. A modalidade de financiamento que nos interessa, na qual o financiador não possui recursos para financiar, mas apenas o nome e prestígio indispensáveis para os obter, é uma modalidade de operação diferente, que se consolidou há pouco mais de um século, na Inglaterra, e depois se elaborou e estruturou definitivamente nos Estados Unidos, de onde se estendeu a outros países.

Os nossos tratadistas, quando falam de concessão de crédito, e embora os seus princípios continuem válidos, não cogitavam desta modalidade específica. Referem-se, em geral, ao crédito bancário concedido segundo as formas tradicionais ${ }^{20}$.

Para Carvalho de Mendonça, "O contrato de abertura de crédito é aquêle, mediante o qual, um dos contratantes se obriga a por à disposição de outro fundos até deter-

19. Donadro, GiUseppe, Sulla. Natura Giuridica dell Apertura di Crédito in "Banca Borsa Titoli di Credito", Dott. A. Giuffré Editore. Milano 1937, fascículo n. 1 "Quale é l'efetto immediato del contratto? Tecnicamente, da parte della banca accreditante - l'accantonamento di una soma di danaro per potese far fronte agli ordini del cliente accreditado - la intestazione di un conto al nome di lui e l'avviso, fatto tenere ad esso, di essere pronta ad eseguire $i$ suoi ordini; economicamente, la privazione del godimento della somma di danaro accantonato; giuridicamente, l'obbligo di mettersi in condizione di soddisfare gli obblighi del cliente, nei limiti della somma accreditata e con la modalita concesse per la sua utilizazione", p. 138.

20. Ferreira, Waldemar. Em sua obra Instituições de Direito Comercial. Vol. III, Os Contratos Mercantis e os Títulos de Crédito, se refere a carta de crédito, forma em que o nosso Código Comercial trata do contrato de crédito, dizendo que os seus elementos específicos são: a) a determinação nominal do creditado e b) a limitação da 
minado limite"21. Evidentemente não é esta a obrigação da Financiadora para com o creditado. A Financiadora não empresta fundos, entre outras razões porque não possui fundos para essa finalidade. Com maior razão não se obriga a por fundos imediatamente ao dispor do financiado.

A frase "por fundos à disposição, deixa em relêvo que, concluído o contrato, o creditador obriga-se a desde então abrir o crédito ao outro contratante".. O creditado adquire desde logo o direito de dispor dos fundos postos a seu crédito, sendo-lhe permitido, quando queira, tornar atual a obrigação do creditador.

Tudo isso se deve levar em consideração quando consideramos o "contrato de abertura de crédito" que fundamenta as "Letras de Câmbio". Não se pretende corrigir a natureza do "contrato de crédito", para o contrato que realizam a Financiadora e o creditado, mas sim notar que a função da Financiadora não é a mesma que nas operacões de crédito tradicionais desempenhava o creditador, porque resumindo:

a) A função da Financiadora não é conceder crédito com os seus próprios recursos mas outorgar o seu aceite, a fim de que o financiado obtenha assim o crédito que necessita e

quantia posta ao seu dispor, p. 179. Nesse "posta ao seu dispor", evidentemente há uma simultaneidade, que no caso do crédito concedido pelas Financiadoras inexiste.

Gomes, OrLando. Em sua recente obra Contratos também considera precìpuamente o contrato tradicional bancário. Diz à p. 326: "A abertura de crédito é o contrato pelo qual se obriga um Banco a colocar à disposição do cliente determinada soma para ser utilizada, no todo ou parceladamente" Vemos aqui êste contrato fundamentado no "mutuo" entre um Banco, como mutuante, e o cliente como mutuário. O mutuante põe à disposição do cliente determinada soma - a qual será movimentada "ad nutum" pelo cliente, sacando contra ela desde o primeiro momento.

21. Tratado de Direito Comercial, vol. VI, 265. 
b) A Financiadora não credita ao financiado recursos próprios, mas os recursos especialmente levantados de terceiros, graças às Letras de Câmbio.

Concluindo, parece-nos que para uma maior precisão conceitual, quando nos referimos a êstes contratos de crédito deveríamos sempre chamá-los "contratos de crédito de aceitação", ou "por aceitação"22. A seguir passaremos a estudar mais pormenorizadamente esta especialidade de crédito.

10. O crédito de aceitação que, repetimos, é o tipo de crédito em que se especializam as Companhias de Crédito e Financiamento, embora não seja novidade no comércio de dinheiro, tem um aspecto que convém salientar neste estudo. Esse aspecto novo é, numa palavra, a sua "institucionalização".

Vejamos, em primeiro lugar, em que consiste o crédito de aceitação. Poderíamos definí-lo como o aceite que o banqueiro (ou uma sociedade solvente) apõe na Letra de Câmbio sacada contra êle, a fim de que se possa descontála fàcilmente, em benefício do sacador, aproveitando-se assim o crédito que inspira o aceitante.

O Dr. Corcelle, no trabalho citado, expõe essas mesmas idéias da maneira seguinte: "Uma abertura de crédito por aceitação significa sempre o saque - por outra

22. Outra denominação genérica possível seria a de "contratos de financiamento", já que o têrmo financiamento é mais amplo que o vocábulo "crédito". O crédito é uma espécie de financiamento: o financiamento imediato. Teríamos então um gênero mais amplo, o gênero "contratos de financiamento", que poder-se-ia dividir em "contratos de crédito", "contratos de financiamento por aceitação" e ainda outros. Não nos parece conveniente, contudo, sugerir nenhuma mudança de nomenclatura, porque os inconvenientes que traria, dado o uso introduzido de longa data, não compensaria a clareza conceitual que pudesse aportar. Por outro lado, trata-se de conceitos em formação, ainda imaturos. 
parte absolutamente regular - duma Letra de Câmbio sôbre um banqueiro que empresta a sua assinatura, o aceite por parte dêste, e a negociação com outro banqueiro descontador" 23 .

E ainda Corcelle acrescenta outra característica que convém considerar: "Por último - diz - não deixaremos de assinalar êste outro rasgo comum a quaisquer modalidades de crédito por aceitação, que é o que torna possível o uso do crédito do qual goza um banco (o aceitante) sem nenhuma imobilização de fundos por parte dêste" 24 .

Disto tudo podemos enumerar uma série de características do crédito de aceitação:

$\left.1^{\circ}\right)$ O saque duma pessoa que necessita de dinheiro, contra um banqueiro que não é devedor dela.

$2 .^{\circ}$ ) A aceitação da cambial por parte do "banqueiro de aceitação", que não empresta dinheiro algum.

$\left.3 .^{\circ}\right)$ A negociação subseqüente da Letra aceite, por outro banqueiro. É por conseguinte um título preparado, na fase pré-institucional, para o desconto bancário.

Ainda poderíamos acrescentar uma quarta característica complementar que é a provisão de fundos por parte do sacador e em tempo hábil, a favor do banqueiro sacado. Mas esta quarta característica pertence à fase diríamos post-bancária do crédito de aceitação ou fase institucional. Enquanto o crédito de aceitação era realizado pelos banqueiros tradicionais, a provisão não tinha grande relêvo ${ }^{25}$.

23. Corcelle, Carlos: op. cit., p. 4304.

24. Corcelle, Carijos: op. cit., p. 4305.

25. Resumindo, e para dar forma às idéias expostas, diríamos que o "crédito de aceitação", conhecido de longa data e praticado circunstancialmente pelos Banqueiros tradicionais, foi ganhando corpo até chegar a institucionalizar-se. Surge então um novo tipo de banqueiro, o "banker's acceptance" que não recebe depósitos nem concede empréstimos, como os banqueiros tradicionais, mas que se especializa no aceite - e nas formas de provisão, como um pré-requisito da aceitação. 
11. A fim de aprofundar mais no crédito de aceitação, que é uma instituição importante para a boa compreensão do nosso estudo, convém mencionar embora sumàriamente as operações em que vem sendo usado, e em que ainda se utiliza.

a) 0 crédito documentário de aceitação - Usa-se no comércio internacional. Pressupõe uma transação de importação-exportação ${ }^{26}$.

O importador começa por abrir, com o seu banqueiro, um crédito a favor do exportador. Éste emite a seguir as Letras contra o banqueiro que, aceitando-as, as remeterá de volta a fim de que o exportador-vendedor possa descontá-las.

Naturalmente, o banqueiro aceitante não aporia o seu aceite se não tomasse outras precauções a fim de garantir a devida provisão. Essas garantias são dadas com os documentos que recebe através do banqueiro (correspondente) que descontou as cambiais do exportador: o conhecimento de embarque, o frete, a apólice de seguro, etc.. Ésses documentos só os entrega ao importador contra a cobertura, ou então serão trocados por outras garantias que assegurem a provisão.

b) O aceite para levantamento de recursos — $\mathrm{E}$ um crédito de aceitação bem semelhante ao nosso. Os Bancos aceitam letras sacadas contra êles, por algum cliente, a

26. "O Instituto tem a sua origem na prática adotada por importadores ingleses, em fins do século XVIII, de obter, para maior garantia dos exportadores estrangeiros, o aval de comerciante de grande reputação, mediante o pagamento de uma comissão, cujo dispendio era compensado pela facilidade em negociar os títulos assim avalizados. Pouco a pouco, êsses mesmos comerciantes passaram de avalistas a aceitantes, mudando da posição de garante para a de devedor principal, evoluindo, assim, para o papel de banqueiros, conhecidos sob a designação de "marchant bankers". Jean Escarra, Course de Droit Comercial, Paris, 1952, p. 972, nota 1. Transcrito no parecer dos Prof Sylvio Marcondes e Helio Rodrigues - em bibliografia. 
quem pela baixa disponibilidade, por exemplo, não poderiam atender sob pena de se ocasionar um descoberto em caixa. O próprio banco aceitante, geralmente, se encarrega de descontar as aceitações, a fim de atender o cliente com os recursos obtidos.

É uma operação pouco interessante para o banco: a baixa liquidez é passageira, e os saques o obrigam durante um prazo ordinàriamente demasiado longo. De resto, os Bancos têm outros procedimentos (o redesconto, por exemplo) para salvar as situações momentâneas de baixa disponibilidade.

c) Regularização da balança comercial - Ainda se tem usado o crédito de aceitação para normalizar desequilíbrios entre as balanças de dois países. O país. devedor, nessa circunstância, aceita os saques do credor.

Usa-se ademais em alguns outros casos; mas, note-se bem: sempre se trata de operações esporádicas, secundárias ou complementares. O uso maior e mais conhecido que se tem feito é precisamente no "crédito documentário", cuja função complementar, consiste em ser instrumento de liquidação nas operações de comércio estrangeiro. A aceitação, efetuada pelos banqueiros tradicionais, é sempre um meio acidental no contexto bancário.

12. É difícil que surjam novidades. Todos sabem que o que se chama muitas vêzes "novo" é "antigo". As novidades freqüentemente consistem em destacar algum aspecto de coisas conhecidas. No nosso caso, a novidade consiste em se ter institucionalizado uma especialidade de crédito.

$O$ crédito de aceitação já era praticado no comércio de numerário, tendo um uso restrito, segundo já se viu. Era uma operação mais de caráter auxiliar, dentro do que era realmente importante: o comércio de crédito.

Quando o banqueiro aceitava o saque, contra êle emitido, normalmente não cuidava de garantir "a priori" a 
provisão de fundos, pôsto que o aceite descansava na confiança que merecia o sacador.

Finalmente, a letra aceita tinha um desconto certo e até predeterminado. Habitualmente, outro banqueiro a descontaria.

À volta da aceitação construíu-se, no nosso século, todo um mercado que alcança proporções gigantescas. No Brasil, o mercado é recente è começou a ser regulamentado em 195927; as primeiras instituições no ramo tinham aparecido poucos anos antes.

As Companhias de Crédito e Financiamento têm como atividade precípua a aceitação e, à volta dela, gira tôda a sua atividade, que essencialmente consiste em:

$10^{\circ}$ - Seleção das pessoas (físicas ou jurídicas) às quais possa dar o aceite;

$2 .^{\circ}$ - Garantir a provisão de fundos do sacador, na altura do vencimento dos saques.

Temos portanto, com a institucionalização do aceite, a institucionalização de um contrato de provisão, que é o suporte e a causa daquele.

$\mathrm{E}$ à volta desta atividade básica se desenvolve tôda uma atividade auxiliar: de "contrôle", contábil, cadastral, cobrança, colocação das cambiais etc. que dá lugar a outros tantos setores de atividades e que contribuem ainda mais para, no mundo dos negócios, se colocarem as financiadoras entre as instituições financeiras de rea! importância.

A colocação das Letras de Câmbio, para concluir, é outro dos aspectos que convém destacar, porque a institucionalização dêstes títulos acarretou a criação dum mercado, inteiramente novo, que absorvesse as aceitações: já se não tratava de cambiais que os próprios banqueiros

27 Portaria 309 de 30.11 .1959 . "Regula a constituição, o funcionamento e as atribuições das sociedades de crédito, financiamento ze das de investimento" 
descontariam, mas de uma quantidade enorme de papel que, com a sua institucionalização, iria necessitar, como complemento necessário da formação de um mercado prédeterminado de capital ${ }^{28}$.

13. Na linguagem comum, quando se coloca a cambial com os particulares, diz-se que se vende a Letra. Conviria aprofundar em que consiste mais exatamente esta colocação, qual a natureza jurídica dêsse fato.

Antes de proceder a outras considerações, comecemos por analisar o fato em sí. Consideremos, em primeiro lugar, que alguém necessitado de financiamento sacou determinadas cambiais contra uma instituição acreditada - a Companhia de Crédito e Financiamento - que as aceitou. Trata-se, por conseguinte, de excelentes títulos especialmente elaborados para realizar dinheiro — do qual precisa o sacador.

As cambiais em questão têm um vencimento futuro -a 180 dias ou mais ${ }^{29}$ - e tem outrossim um determinado valor no vencimento.

Falar, no caso, em venda de títulos seria usar uma noção excessivamente ampla ${ }^{30}$. Tôda a transferência da

28. Convém salientar neste mercado o papel de duas instituições, as Sociedades Corretoras e as Distribuidoras. Estas sociedades são comerciantes no sentido técnico-mercantil de comprar para revender. Adquirem as Letras das Companhias para, em seguida, vendê-las entre os aplicadores ou compradores.

A Companhia de Financiamentos também pode vender diretamente as Letras, no qual caso, além da mercantilização do aceite (que lhe é própria) realiza também atividade comercial da venda da Letra como os Corretores ou Distribuidores.

29. “As Sociedades de Crédito e Financiamento têm por objetivo praticar operações que se relacionam com a concessão do crédito a médio e longo prazos" .. (art. III da Portaria 309 de 30.11.1959).

30. Fica excluída a compra e venda mercantil, que tem sempre um caráter intermediário: comprar para vender. No nosso mercado, poder-se-ia falar de compra e venda de cambiais, quando as Sociedades 
propriedade de bens, contra a entrega dum preço, é uma venda. Evidentemente, quando a Companhia de Financiamento, diretamente incumbida pelo financiado de realizar as cambiais, as transfere para o adquirente contra a entrega de determinada importância, está "vendendo" as cambiais. Contudo, não se pode esquecer: 1) que a mercadoria vendida são títulos de crédito, 2) que o preço estipulado está em função de um prazo e de um determinado valor no vencimento e 3) que se adquire a propriedade dos títulos exclusivamente para auferir-lhes o valor que têm do resgate. $O$ aplicador não tem o "animus adquirendi" não lhe interessam os títulos em si.

Após lembrar estas noções, passaremos ao estudo do desconto.

14. As teses mais representativas acêrca do desconto (ademais da compra-venda tratada acima) são duas: cessão antes do têrmo da provisão e empréstimo sob o título 31 .

corretoras adquirem as "aceitações" para, a seguir, vendê-las aos particulares. Diz o artigo 191 do Código de Comércio: " $\mathbf{E}$ ùnicamente considerada mercantil a compra e venda de efeitos móveis. para os revender: compreendendo-se na classe dos efeitos móveis a moeda metálica e o papel moeda, títulos de fundos públicos, ações de Companhias e papéis de crédito comerciais, contanto que nas referidas transações o comprador ou vendedor seja comerciante"

31. A primeira teoria se fundamenta em que os títulos de crédito só se tornam efetivos no vencimento. A essência do negócio jurídico consistiria em ceder pura e simplesmente o referido título, antes do seu vencimento, por um valor inferior.

Para outros, entretanto, partidários da segunda teoria, não há senão um mútuo ou empréstimo de dinheiro. $O$ título se recebe em caução - como garantia de recebimento do principal mais os juros, na data do vencimento. A alguns tem parecido que o nosso Código Comercial acolhia esta segunda teoria, pelo fato de ter incluído o têrmo "desconto" dentro do Título XI, da Primeira Parte, que trata precisamente do Mútuo. Com efeito, o artigo $255 \mathrm{diz}$ : “Os descontos 
O desconto de títulos porém é um instituto genuino de direito mercantil, ao qual o direito civil pode dar algum subsídio $^{32}$ mas sem chegar a penetrá-lo em tôda a sua dinamicidade.

Uma noção exclusivamente mercantilista seria aquela que considerasse, em concreto, os títulos de crédito. Desconto então seria "o endôsso dum efeito de comércio a favor dum banqueiro, que paga o montante ao endossante, menos a dedução duma soma que representa os juros do montante do efeito, que correm antes do vencimento" 33 .

Nesta noção fala-se em endôsso, mas poder-se-ia falar, mais amplamente, em transferência do título. $O$ endôso aplica-se na transferência de títulos nominativos e consiste simplesmente em o seu titular assinar no verso. Os títulos ao portador transferem-se pela simples "traditio" — sem que seja necessário o endôsso.

Uma noção, por conseguinte, mais universal seria aquela que considerasse o desconto como: a transferência de um título de crédito, a favor de outro, que paga o valor do vencimento menos a dedução de uma certa soma.

Esta é precisamente a conceituação dos mais modernos mercantilistas. Entre nós, Waldemar Ferreira chega a dizer que tôda a vez que se adquire um título de crédito,

de letras de câmbio ou da terra, e de quaisquer títulos de crédito negociáveis, regulam-se pelas convenções das partes" Não se regem, por conseguinte, pela norma geral, mas pela convenção particular; o desconto seria, pois, um "mútuo particular"

32. Ripert, Georges, Traité élémentaire de Droit Commercial. v edição, Paris, 1963, p. 934.

33. O direito civil conhece a figura do mútuo frugífero, realizado com o intuito de auferir um juro ao empréstimo. "Permitido é fixar, por cláusula expressa, juros ao empréstimo de dinheiro ou de outras coisas fungíveis. Passa a ser, então, contrato oneroso, denominando-se, mútuo feneratício ou frugífero" V. Gomes, ORLando, Contratos, Companhia Editora Forense, Rio de Janeiro, 1966, p. 316. 
antes do vencimento, por um valor inferior, está-se efetuando uma operação de desconto.

Quando, no mercado de "Letras de Câmbio", as Companhias de Crédito as transferem aos tomadores, por um valor inferior ao do vencimento, êstes nada mais fazem (nem nada menos) do que descontá-las.

Assim poderíamos notar que o desconto, pelo fato de ser um instituto comercial, reservado a comerciantes, não serviria para caracterizar o fato da colocação das Letras. De qualquer maneira, convém salientar que, em conformidade com o que temos analisado, a operação, no caso, é de desconto - os aplicadores descontam as aceitações. Trata-se, porém, dum "desconto particular", e não de desconto bancário, que só realizam instituições devidamente autorizadas.

15. Desta análise resulta que o crédito é concedido pelos particulares, pelos portadores das cambiais, que são os descontantes dos títulos.

Fundamentando ainda mais esta idéia, lembramos que a função da Companhia de Crédito e de Financiamento é a de mediador entre o tomador e o sacador, entre o mutuante e o mutuário, entre aquêle que oferece seus próprios recursos e aquêle que os recebe, entre o descontante e o descontado.

A Financiadora, por construção, não empresta. Não tem recursos próprios para descontar cambiais, nem para conceder crédito. Já vimos que sua atividade consiste em dar a confiança que ela inspira, dando o aceite, e realizar as demais tarefas decorrentes disso ${ }^{34}$.

34. Transcrevemos um trecho do Prof. AMÉRICo Oswaldo CAMPIGLIA, para confirmar esta caracterização: "Operando, essencialmente, na base do Crédito Fiduciário, as emprêsas financeiras não emprestam dinheiro, como errôneamente muitos supõem, mas realizam um serviço de captação de recursos com sua responsabilidade solidária, 
Aliás, o papel dos tomadores, como descontadores das "aceitações", vê-se comparativamente, lembrando como eram os Bancos os que acabavam descontando as cambiais - que tinham sido aceitas por outros estabelecimentos bancários - e como continuam sendo Bancos os que descontarn as letras dos créditos documentários, e das demais operações de aceitação, quando se praticam a nível bancário. Os descontadores particulares realizam a mesma função dos Bancos-descontadores, fazem as vêzes dêles.

Por êste caminho se chega à conclusão de que o que temos no caso é uma única operação de crédito $^{35}$, concedido pelos portadores quando "descontam particularmente" as cambiais, a favor dos respectivos sacadores. A Financiadora é simples mediadora; situa-se entre as duas partes, como uma ponte que põe em comunicação as duas beiradas dum rio.

\section{Conclusões}

1. O uso do crédito de aceitação, por parte das Financiadoras em grande escala, representa um fenômeno revolucionário do crédito no mercado de capitais.

2. Um fenômeno concomitante: a institucionalização e comercialização do aceite cambiário e a criação de um mercado novo que poupa em "cambiais das Financeiras".

mediante o financiamento entre o mercado e as emprêsas financiadas". Transcrito do Suplemento Econômico publicado a 30.1 .68 pela Consultoria da Imprensa Brasileira Ltda. - CIB, da homenagem prestada pela ACREFI ao Prof. Antonio Delfim Neto.

35. Deixamos êste ponto de vista apenas aflorado neste trabalho, sem pretender aqui tôdas as conclusões. A fusão das duas vertentes do negócio, ou seja, as relações: financiado - financiadora e financiadora - tomador das Letras de Câmbio, numa só operação de crédito e desconto levar-nos-ia a alguns problemas novos que ultrapassariam os limites dêste pequeno trabalho. 
3. Existe uma única operação de empréstimo: é a realizada pelo particular que desconta a Letra de Câmbio; a Financiadora se obriga com seu aceite. É simples intermediária e co-obrigada entre as partes.

4. A Letra de Câmbio, que se adotou foi a Letra de Câmbio - diríamos - tradicional brasileira. Conviria, entṛetanto, dar uma especial proteção a êsse título por parte das autoridades monetárias, por estar a serviço da poupança popular. De resto as Financiadoras poderiam utilizar outros títulos, para realizar suas atividades.

\section{Adendo}

\section{Alguns aspectos Tributários das Cias. Financiadoras.}

I. As cambiais, pelo sistema estudado, se converteram em instrumento excepcional de poupança ${ }^{1}$ e de financiamento. Se não houvesse poupança inexistiria o financiamento e recìprocamente: êste é ocasião de poupança. São as duas faces duma mesma moeda. Estão intimamente relacionadas e interdependentes. $\mathrm{Na}$ atividade bancária a inter-relação entre os depósitos e os créditos concedidos é - como já dissemos - diferente, porque se trata de setores que se relacionam segundo técnica tipicamente bancária.

O conta-correntista não tem consciência de investidor ou aplicador, apenas é depositante, tem passivamente o dinheiro no Banco. Os que aplicam as suas economias

1. O estímulo da poupança é uma das metas do Govêrno, que, entre outros meios, deve fomentá-la com a sua "Política Tributária", a qual tem por objeto: "o estímulo à formação de poupanças individuais (pela dedução das poupanças no cálculo da renda tributável)". Programa de Ação Econômica do Govêrno 1964-1966. Documentos EPEA n. ${ }^{\circ} 1$, p. 77. 
em Letras de Câmbio de Financiadoras têm consciência de investidores, de financiadores.

A atividade das Companhias de Crédito e Financiamento é diversa da bancária. Aquêle que poupa adquirindo "cambiais" sabe certamente em poder de quem estão os recursos que aplica: porque as operações são pré-determinadas e na cambial consta o nome do sacador-financiado. Evidentemente que a Companhia é devedora como primeiro coobrigado que é do tomador; mas isto não evita: $1 .^{\circ}$ que o financiado também seja devedor, $2 .^{\circ}$ que o portador da cambial conheça e queira financiar o financiado.

Êste mecanismo natural de seleção, exige um maior sentido de responsabilidade à Companhia, que não pode conceder o seu aceite arbitràriamente, já que logo veria decrescer o seu prestígio. A pessoa física ou jurídica que desconta as Letras de Câmbio se informa habitualmente, e está a par, na medida de suas possibilidades, do andamento dos negócios.

o "banker's acceptance" constitui-se, por esta forma, num banqueiro exposto às vistas de todos, o que faz que a sua atividade seja extremamente cuidada. $O$ sucesso dêle radica no acêrto na prestação do aceite.

Uma faixa determinada de poupança dos países, freqüentemente uma larga faixa, fica assim aplicada em setores de interêsse por êste processo natural de autodisciplina, por êsse mecanismo que implica responsabilidade. E o critério experimentado dos "banker's acceptance" e dos aplicadores - em conformidade com as diretrizes das autoridades crediticias.

II. Não vamos enumerar, nêste trabalho, um por um, os impostos que incidem sôbre a atividade das financiadoras porque seria sair do objetivo dêle.

Os impostos que mais pressão exercem sôbre elas são os impostos cobrados pela União e principalmente o im- 
pôsto de renda. Êstes impostos atingem principalmente às suas atividades em três momentos diferentes:

$\left.1^{\circ}{ }^{\circ}\right) O$ impôsto sôbre operações financeiras: que incide sôbre o valor do principal acrescido: da correção monetária e das despesas de financiamento tais como a comissão de aceite e a corretagem. Este impôsto calcula-se atualmente na base de $1 \%^{2}$.

$\left.2^{\circ}{ }^{\circ}\right) \quad O$ impôsto de renda chamado comumente de "identificação". Êste impôsto incide sôbre a renda além da correção monetária oficial auferida pelo tomador da cambial $^{3}$, e é de $15 \%$. caso o tomador se identifique ${ }^{4}$ e de $40 \%$ caso não se identifique. ${ }^{5}$

$\left.3 .^{\circ}\right)$ Os impostos sôbre o lucro das pessoas jurídicas ${ }^{6}$ que no caso das Financiadoras está formado principalmente pela soma das comissões de aceite.

2. Lei 5.143 de 20 de outubro de 1966 .

3. Não é considerada renda a correção monetária oficial, ou seja aquela que assinala o índice mensal do Consêlho Monetário Nacional. Por conseguinte é preciso subtrair da correção pré-fixada pela Companhia o valor da Correção Oficial. Não entramos, nêste trabalho, em maiores pormenores de natureza fiscal, por não ser êsse o intuíto do trabalho. Entrètanto, note-se que esta mesma parcela gravada pelo "impôsto de renda" de identificação, já foi gravada pelo I.o.F., mencionado no item $1 .^{\circ}$.

4. Art. 306 do Decreto 58.400 de 10.5.66 (Regulamento do Impôsto de Renda).

5. Estava já êste trabalho no prelo, quando, no último dia do ano 1968, foi promulgado o Decreto-Lei n. 403 que suprimiu o empecilho da identificação para os aplicadores. Êsse Decreto-Lei, no art. $4 .^{\circ} \S 1 .^{\circ}$ diz: "Quando o beneficiário do Rendimento for pessoa física, será dispensável sua identificação, sendo o imposto devido exclusivamente na fonte."

6. Na atualidade vigora o Decreto-Lei n. 62 de 21.11.1966, que assinalou como valor do impôsto $30 \%$ dos lucros (art. 1. ${ }^{\circ}$ ) mais o adicional de $10 \%$ (art. $2 .^{\circ}$ ). Estima-se que o impôsto sôbre os lucros, não havendo lucros extraordinários, representa $15 \%$ aproximadamente da comissão de aceite da Companhia, que é atualmente $6 \%$ ao ano. 
$4^{\circ}$ ) Poderíamos ainda falar do impôsto que grava os dividendos dos acionistas. Como em definitivo, o capital da pessoa jurídica é dêles, os rendimentos, globalmente considerados, são atingidos duas vêzes: como lucros da sociedade e, quando distribuídos, como dividendos ${ }^{6 a}$.

Deixamos todavia de parte outros gastos que origina o financiamento, que não são de ordem fazendária. São os gastos de corretagens, calculados, atualmente, na base de $3 \%$ ao ano e do registro das operações em Bolsa que é 0,25\%. Estas percentagens calculam-se também sôbre o valor do crédito. Não obstante ponhamos de parte essas despesas, devem ser levadas em conta à hora de calcular o custo do dinheiro. Interessa apenas salientar que pelo fenômeno natural da repercussão, tôda ${ }^{7}$ despesa repercute sôbre o financiado, encarecendo o dinheiro. E convém ainda notar que, no negócio de Financiamento, a União, levada em consideração tôda a tributação, ganha mais do que a própria Financeira. A Companhia tem de cobrir os seus gastos gerais, de administração, serviços e demais que representam $50 \%$ da receita bruta. Porisso o ganho líquido da Financiadora é menor do que o que arrecada o Fisco.

Esta pressão tributária, deve-se dizer, não é parcial pelo contrário o impôsto em questão grava acremente tôdas as áreas da economia nacional, sendo esta uma a mais. 0 impôsto de renda representa aproximadamente $35 \%$ da receita total da União ${ }^{8}$, disputando a primazia com o impôsto de consumo. Como é sabido, o Brasil se conta entre os dez países de mais alta tributação, inclui-se

6a. Art. 125. "Estão sujeitos ao desconto na fonte, à razão de $10 \%$ (dez por cento).. d) os lucros, dividendos, bonificações... "Decreto 58.400 de 10.5.66".

7. Quando dizemos tôda, se está incluindo também o impôsto de renda, que grava o portador das cambiais, a que nos referimos nêste mesmo item.

8. Bueno, LuIz de Freitas e outros. Aspectos Gerais da Receita Pública no Brasil, em apostilhas, sem imprimir, São Paủo, 1962, p. 31 . 
entre os países que obtém uma renda "per capita" acima de US $\$ 1.000$, quando a renda "per capita" do nosso povo é da ordem de US $\$ 160^{9}$.

III. O direito fiscal, dado o seu fim, essencialmente econômico pode orientar-se, e de fato se orienta em muitas ocasiões, com autonomia à margem do direito comum, visando os fins que lhe são próprios.

Nunca a fiscalidade se deverá entravar por exigências doutrinais; daqui decorre que nem sempre a consideração dos institutos jurídicos coincide na esfera fiscal, com a esfera do direito comum. Esta noção, que muito ajudaria a resolver o eterno litígio entre o fisco e contribuinte, deve-se levar especialmente em conta, em se tratando das Letras de Câmbio das Financiadoras, que suscitariam várias questões doutrinárias e fiscais.

Outro assunto é política fiscal, intimamente ligada às contigências e situações do momento, em cada país, visando o resultado nacional - não apenas maior arrecadação.

9.

\begin{tabular}{|c|c|c|c|c|}
\hline & Países & Tributos sôbre o $P N$ & \multicolumn{2}{|c|}{ Renda "Per Capita" } \\
\hline 1 & Itália $\ldots . .$. & $42 \%$ & US\$ & 995 \\
\hline & França .. ... & $37 \%$ & US\$ & 1.498 \\
\hline 3 & Alemanha $\ldots$ & $35 \%$ & US\$ & 1.648 \\
\hline 4 & Luxemburgo & $33 \%$ & US\$ & 1.619 \\
\hline 5 & Reino Unido .. & $33 \%$ & US\$ & 1.607 \\
\hline 6 & U.S.A. $\quad \ldots$ & $31 \%$ & US\$ & 2.853 \\
\hline 7 & Finlândia ..... & $30 \%$ & US\$ & 897 \\
\hline 8 & Dinamarca $\quad .$. & $28 \%$ & US\$ & 1.557 \\
\hline 9 & Brasil $\quad \ldots .$. & $27 \%$ & US $\$$ & 159 \\
\hline 10 & Canadá $\quad . .$. & $27 \%$ & US\$ & 2.011 \\
\hline
\end{tabular}

"An Econometric Analysis of the Brazilian Tax Structure", em apostilhas sem publicar, São Paulo, 1967, p. 3. Dados citados com permissão especial do autor, GIAN S. SAHOTA. Faculdade de Economia da USP. 
Reconhecendo, por conseguinte, a autonomia fiscal para gravar quaisquer parcelas, quantas vêzes se quizeer ${ }^{10}$ ¿ ainda a independência fiscal na consideração dos institutos, deve-se notar o seguinte:

$\left.1 .^{\circ}\right)$ que nunca uma lei tributária anterior ao aparecimento de fatos novos (como são a mercantilização do aceite, as operações de crédito de aceitação, a correção monetária) pode ter incluído êstes sob a sua aplicação. "Nullum tributum sine lege".

$\left.2 .^{\circ}\right)$ que não se devem precipitar os práticos (contadores, executivos) na inclusão de fatos posteriores sob a alçada de leis fiscais precedentes.

Paga-se o impôsto sôbre a renda dos aplicadores em "Letras de Câmbio ao portador"11, por exemplo, sem um

10. Nâo vamos discutir aqui o velho problema do direito tributário do "bis in idem", ou seja de se o Fisco pode gravar duas ou mais vêzes a mesma parcela. "Nenhuma restrição se pode opôr a constitucionalidade da tributação dupla ou múltipla, quando exercida com ânimo deliberado e fundamento legal, pelo mesmo govêrno competente, desde que não exceda limites expressos fixados na carta política. Em geral, o poder de impôr é exercido sempre de modo a conservar a fonte tributável". Aliomar Baleeiro - "Bis in idem", no Repertório Enciclopédico do Direito Brasileiro" de J. M. DE CARvalHo Santos. Vol. 6, p. 23.

Entretanto parece-ros questionável a bitributação. “Aberta, porém a possibilidade da criação de novos impostos - de impostos não discriminados expressamente - mediante o art. 21, que veio a outorgar possibilidade à União e aos estados, com exclusão dos municípios, de sua decretação, haverá de surgir ensejo para verificação de bitributação. Com efeito, o art. 21 da Constituição admite possam a União e estados instituirem impostos não previstos" Geraldo AtalIBA: "Bitributação" em "Revista de Faculdade de Direito", Vol. LX, S. Paulo, 1965, p. 203.

11. Decreto Lei 58.400 de 10.5.66, Livro V (Sôbre casos especiais de arrecadação das fontes pagadoras), Título I (a incidência do impôsto), Capítulo III (do deságio) Seção I (da tributação até o exercício 1966) e Seção II (da tributação a partir do exercício de 
fundamento claro; sem se ter aprofundado nos fatos novos e sem ter, porque não houve tempo para isso, uma visão de conjunto do novo fenômeno ecônomico-financeiro da correção monetária, por exemplo, e de sua significação. Não vamos entrar nêste trabalho no fundamento legal dêsse impôsto de renda, mas repare-se que o art. 54 da Lei 4.728 - no qual se apoia a Resolução n. ${ }^{\circ} 45$, item $X$, letra C, do Banco Central — não trata dos juros sôbre Letras de Câmbio.

Evidentemente que quando se fala aqui de "fatos novos", não pensamos em fatos repentinos, mas em fatos que paulatinamente vão-se configurando. Por isso é mais difícil avaliá-los, porque a sua transformação é lenta, embora constante e profunda. É natural que as leis fiscais venham depois dos fatos econômicos.

Estamos finalmente hoje perante um importantíssimo mercado de capitais $^{12}$ que se conseguiu formar graças a entidades financiadoras autorizadas, as quais institucionalizaram a tradicional "aceitação" e jogaram simultâneamente com o anonimato dos aplicadores - que a nossa lei permitia.

1967), a.306 — “está sujeito ao desconto do impôsto na fonte, à razão de $15 \%$, o deságrio concedido na venda ou colocação no mercado, por pessoa jurídica a pessoa física, de debentures ou obrigações ao portador, letras de câmbio ou outros quaisquer títulos de crédito".

$\S 1 .^{\circ}$, a) II exigir a identificação do adquirente e o recibo correspondente ao deságio.

12. Brazão, José Alberto: Mercado de Capitais - Situação Atual e Perspectiva para o futuro, em "Problemas Brasileiros", n. ${ }^{\circ}$ 39, Junho 66. "Que tipo de inversores adquirem as letras de câmbio? Seriam sós os grandes inversores? Não, absolutamente não. Existem de fato, aí invertidos os vultosos recursos de grandes capitalistas. Mas para aí são canalizadas também as poupanças das classes médias e dos pequenos inversores, sempre que estes podem prescindir de suas economias por dado lapso de tempo. As letras de câmbio tem aglutinado, assim, economias de todo o gênero e de tôda procedência” p. 20. 
O legislador fiscal, ainda deverá ter presente o princípio da tendência à evasão $0^{13}$. Não deverá gravar em excesso áreas econômicamente interessantes, já que certamente as reduzirá, e se essas áreas forem incipientes corre o risco de destruí-las. Depois dêstes primeiros anos de experiência conviria estudar profundamente a política fiscal mais conveniente no caso, já que estamos perante um fato ecônomico de altas conseqüências.

\section{Bibliografia}

Ataliba, Geraldo, Bitributação em Revista da Faculdade de Direito, V. LX, S. Paulo 1965.

Ascareuli, Tullio, Teoria Geral dos Títulos de Crédito, Saraiva \& Cia. Editores, São Paulo 1943.

Baleeiro, Aliomar, Bis in iden, no Repertório Enciclopédico do Direito Brasileiro de J. M. de Carvalho Santos, V. 6, Editor Borsoi, Rio de Janeiro, pp. 22 a 30.

Brazão, José Alberto, Mercado de Capitais - Situação Atual e Perspectiva para o Futuro na "Revista da Federação do Comércio do Estado de São Paulo": "Problemas Brasileiros", n. ${ }^{\circ}$ 39, Junho 66, pp. 11 a 26.

Bueno, Lutz de Freitas; Pastore, Affonso Celso e Gitelman, CecíLIA, Aspectos Gerais da Receita Pública no Brasil, sem publicar, São Paulo 1962.

Corceile, Carlos, Créditos por Aceptación en los Bancos, en "Industrias y Finanzas", A. XV, n. ${ }^{\circ}$ 171, Buenos Aires, Março 1936, pp. 4303 a 4308 .

Crusells Ingles, José, Letras de Câmbio, $1 .^{\mathrm{a}}$ edição Editorial Crusells, Barcelona, 1949.

13. O princípio prático da tendência à evasão, diz que o contribuinte muda paulatinamente de atitude, buscando evitar a tributação. o legislador fiscal deve mudar, dependendo do gráu de estabilidade e desenvolvimento civico da sua população, os fatos geradores, a fim de conseguir obter a receita. 
Delfim Netto, Antonio; Pastore, affonso Celso; Cipollari, Pedro e Carvalho, Eduardo Pereira De, Alguns Aspectos da Inflação Brasileira. Estudos Anpes, São Paulo, 1965.

Donadio, Giuseppe, Sulla Natura Giuridica dell Apertura di Credito, in "Benca Borsa e Titoli di Credito", Dott. A. Giuffré - Editore, Milano, 1937, fascículo n. ${ }^{\circ} 1$, pp. 138 a 165.

EPEA, Documentos N. ${ }^{\circ}$ 1, Programa de Ação Econômica do Govêrno 1964-1966. Ministério de Planejamento e Coordenação Econômica. Novembro 1964.

EPEA, Documentos N. ${ }^{\circ}$, O Mercado Brasileiro de Capitais, dirigido pelo Prof. Mario Henrique Simonsen. Ministério do Planejamento e Coordenação Econômica, 2. ${ }^{\mathrm{a}}$ ed. Maio, 1965

Escarra, Jean, Cours de Droit Commercial, Paris, 1952.

Gomes, Orlando, Contratos, Editora Forense, 2. ${ }^{\text {a }}$ ed. Rio de Janeiro, 1966.

Ingles de Souza, Marcos Herculano, Títulos ao Portador no Direito Brasileiro, Rio de Janeiro, Livraria Francisco Alves, 1898.

JANIN, LouIs, Les Societés de Participations, au point de vus economique, Recueil Sirey, Paris, 1928.

LACerda, Paulo DE, Do contratc de Abertura de Crédito, 2. ${ }^{\mathrm{a}}$ ed., Jacinto Ribeiro dos Santos, editor; Rio de Janeiro, 1929.

Marcondes, Sylvio e Rodrigues, Helio, $O$ Crédito de. Aceitação e a Lei do selo Federal. Empresa Gráfica da Revista dos Tribunais S.A., São Paulo, 1961.

Marcondes, Sylvio, Aceites Bancários, São Paulo, 1959.

Mendonça, José Xavier Carvalho DE, Tratado de Direito Comercial Brasileiro, 7.a edição, Freitas Bastos, Rio de Janeiro, 1963.

Messineo, Francisco, Contenuto e Carattere Giuridici dell Apertura di Credito em "Rivista di Diritto Commerciale", Milão, 1925, v. XXIII, $1 .^{\mathrm{a}}$ parte, pp. 118 a 120 .

Nogueira, Ruy Barbosa, Criação e Formalização do débito fiscal: A Lei o fato gerador e o Lançamento, Rev. Trib. 273/48.

PAJISTE, Bernard, Investimentos, 2. ${ }^{\text {a }}$ ed. Edições Financeiras S.A., Rio de Janeiro, 1958.

Pontes, de Miranda, Tratado de Direito Cambiário, V. I, Letra de Câmbio, 2.a ed., Max Limonad, São Paulo, 1954. 
Rezzara, Gumo, Della Apertura di Crédito in conto Corrente, Turim, 1926.

RIPert, Georges, Traité elementaire de Droit Commercial, V Ed. René Reblot, Librairie Genérale de Droit et de Jurisprudence, Paris, 1963.

Souza, Rubens Gomes De, Compendio de Legislação Tributária, 3. ${ }^{\text {a Ed. }}$ Edições Financeiras S.A., Rio de Janeiro, 1960.

Waldemar, Martins Ferreira, Instruções de Direito Comercial, V. III, "Os contratos Mercantis e os Títulos de Crédito", Livraria Freitas Bastos S.A., São Paulo, 1953.

Whitaker, José Mari $\Lambda$, Letra de Câmbio, Saraiva S/A, São Paulo, $1950,4 .^{\mathrm{a}}$ ed. 